\title{
Inter-Ethnic Conflict Management and Prevention in Cameroon's Northwest: Assessing the Role of the Justice and Peace Commission of the Catholic Archdiocese of Bamenda
}

\author{
Michael Kpughe Lang
}

\begin{abstract}
This article analyzes the role of the Justice and Peace Commission (JPC) of the Archdiocese of Bamenda in the management and prevention of inter-ethnic conflicts in the Northwest Region of Cameroon. It demonstrates that the active participation of this institution in peacebuilding is marked by partial success. There is much belief in the capacity of faith-based institutions to manage conflicts. However, evidence on the role of this Catholic Commission in terms of engagement and mediation in peacebuilding among warring ethnic communities is not encouraging. While its dialogue approach has significantly checked violence, its Peace Education Programme has failed to build an entrenched culture of peace. It operates in a context of significant obstacles and direly needs to beef up its operations.
\end{abstract}

Keywords inter-ethnic conflict, Catholic Church, justice and peace commission, Bamenda Archdiocese, Northwest Cameroon

\section{Introduction}

Religion's role as a promoter of both conflict and peace has been established by scholars. But there is a consensus argument among conflict experts that peace and reconciliation are fundamental Christian core values. Churches have enormous credibility which offers them the potential to be suited for aiding peacemaking. This capacity of churches as peace promoters is largely overlooked by scholars, who tend to privilege the crucial role of churches as generators of conflict in society. This trend amounts to the blanket labeling of religion as a source of conflict across the world (Juergensmeyer 2003; Wellman 2007). The use of violence by Christian faith traditions in numerous instances and places 
across the globe is particularly emphasized in ways that obscure churches' role in conflict prevention and mediation. In his introduction to Belief and Bloodshed: Religion and Violence across Time and Tradition, Wellman $(2007,1)$ notes how "religion, conflict, and violence have intersected throughout history and across religious traditions."

In recent decades, this excessive focus on instances of conflict and violence has been brought under heavy criticism by scholars who argue that religion is equally a guarantor of societal peace (Bercovitch and Kadayifci-Orellana 2009; Odoemene 2012). These scholars have sought for decades now to understand how religion has interacted with peace through the lens of faith-based organizations. They agree that the involvement of faith-based organizations in conflict prevention and resolution makes religion a resource for peaceful co-existence. Little wonder Odoemene $(2012,53)$ labels the approach of researching violence only as "lopsided, insufficient, and somewhat misleading." He uses the Catholic Church to illustrate how religion brings peace, stressing that the Church has been able to participate in peacemaking and reconciliation across the world, especially after the Second Vatican Council's call for the Church to pay attention to justice, peace, and human rights. Scholars have acknowledged the capacity of faith-based organizations to be involved in various forms of conflicts at the local, regional, and international levels (Nichols 1994; Sampson 1997; Bercovitch and KadayifciOrellana 2009, 176).

Africa, a continent with a long history of multiple forms of violence and conflict, is in dire need of peace. The continent transitioned from the colonial era against the backdrop of war and violence which manifested as civil wars, ethnic conflicts, inter-state wars, religious conflicts of various sorts, exacerbated intolerance, with ensuing violence against innocent, poor, and powerless people. This violence came with challenges and opportunities for the Catholic Church to work for peace. In countries throughout Africa, the Church has exploited its credibility status in ways that have enabled it to commit to the task of conflict prevention and resolution. Apart from identifying and knocking out the forces that feed conflicts in societies, the Catholic Church has faced conflicts head on in numerous ways: sheltering victims, providing a place for dialogue with perpetrators, serving as intermediaries between conflicting parties, and the like. The Church operates faith-based organizations whose actors are active in conflict zones as educators, mediators, and intermediaries.

An excursion into the conflict resolution literature reveals a recent focus on faith-based organizations' (FBOs) role in conflict prevention and mediation in Africa. In his study, Sampson (1997) acknowledges the capacity of religious actors to participate in conflict resolution as educators, advocates, intermediaries, and pursuers of transnational justice. This capacity of FBOs to play a role in conflict resolution is also emphasized by Appleby (2006), Appleby and Little (2004), and Reychler (1997). Odoemene (2012) studied the conflict management and 
peacebuilding initiatives of the Justice, Development and Peace Commission in Nigeria, observing that the FBO is building a just and peaceful society in Nigeria. Ilo (2015) analyzes the work of the Christian Association of Nigeria to argue that FBOs have the potential to resolve conflicts. He notes that if the Christian Association of Nigeria builds a robust approach, it "can help encourage interfaith relations, manage crisis, negotiate and mediate in conflict situations, serve as a communication link between opposing parties, and provide training in peace making schemes." (ibid., 100). But Haynes $(2009,52)$ has pointed out that efforts by religious organizations in conflict resolution are "characteristically partially successful." According to Haynes, peacebuilding initiatives of FBOs results in either success or partial success. This article subscribes to this contention to demonstrate that the active participation of the Justice and Peace Commission in peacebuilding in Cameroon's Northwest Region has been marked by partial success.

Although there is growing scholarly interest in religious peacebuilding in Africa, it remains an overlooked dimension of conflict resolution in Cameroon. As such, this study aims at filling this gap by assessing the role of the Catholic Justice and Peace Commission in conflict prevention and mediation in the Northwest Region of Cameroon. Numerous ethnic and land conflicts in Cameroon galvanized the Catholic Church into action in an effort to enhance peace and human wellbeing. This led to the establishment of Justice and Peace Commissions in Archdioceses across the country. Created in 1980, the Bamenda Archdiocese was pushed by countless ethnic conflicts, succession disputes, farmer-grazier disputes, and various forms of intolerance to create its Justice and Peace Commission (JPC) in 2002. For close to two decades now, the JPC has worked towards building a culture of peace in an Archdiocese pervaded by a culture of violence.

By spotlighting the perspectives of the JPC on conflict prevention and resolution, I highlight grassroots peacebuilding efforts of faith-based institutions in a world pervaded by violence and conflict. The study argues that faithbased institutions at times fail in avoiding and resolving conflict, not always successful as held by some scholars. The JPC has been partially successful in its peacebuilding efforts. This study examines the ways and means by which the JPC has worked for peaceful coexistence in Cameroon's Northwest Region, analyzing how and why it failed or succeeded in specific inter-ethnic conflict situations. The goal is to complicate the conventional narrative and public view that the JPC in particular and faith-based institutions in general promote peace as a faith imperative with usual success.

The time frame addressed by this article is from 2002, when the Archdiocese of Bamenda created its JPC, to 2018. Though the blueprint of the JPC centered on the transformation of society in which there is respect for human dignity, equality, peace, and sustainable development, it is the peace dimension that is privileged 
Figure 1. Location of Northwest Cameroon

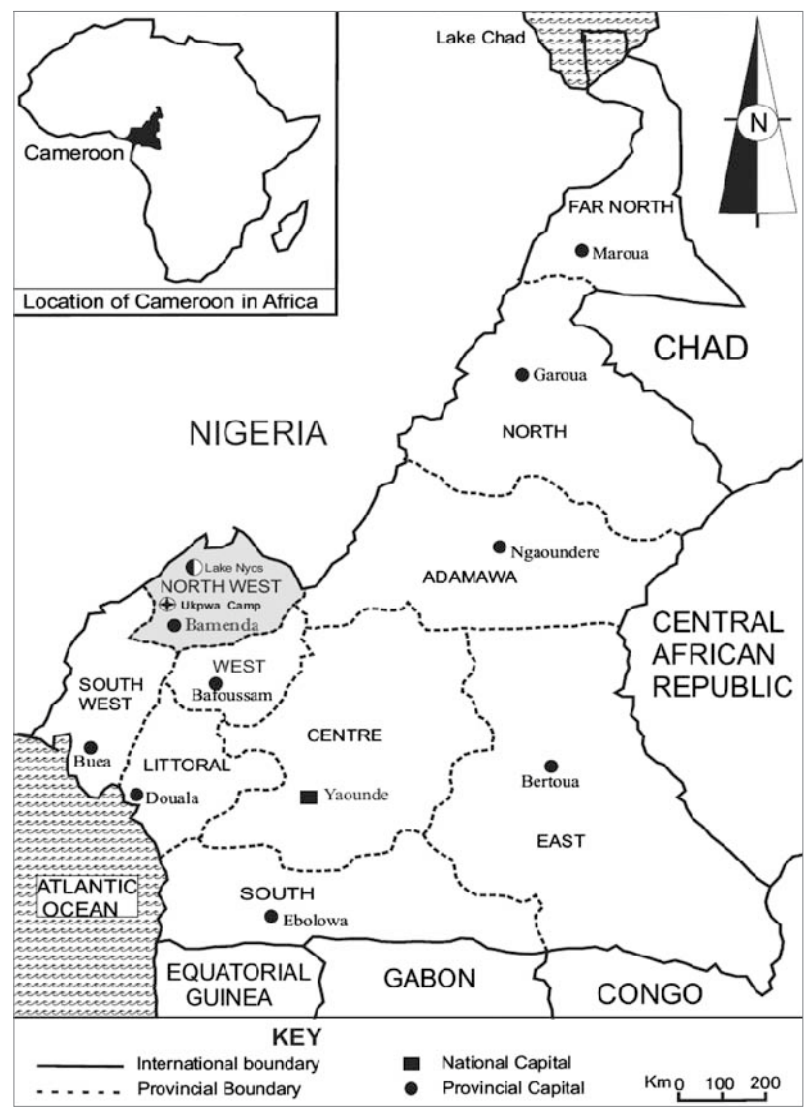

Source: Bang and Few $(2012,1143)$

in this study. Archival materials received from the JPC complement oral history materials collected in Bamenda, Bali, Bawock, Oku, and Mbessa. The locale of the study is the Northwest Region of Cameroon in the Archdiocese of Bamenda, created in 1982 as the Ecclesiastical Seat of the Province of Bamenda (See Fig. 1). The Archdiocese comprises forty parishes all grouped into six deaneries for pastoral convenience (Ndi 2005, 2014). The study covers five out of the seven divisions of the Northwest Region, namely, Mezam, Boyo, Momo, Menchum, and Ngokentunjia. The region is host to numerous centralized chiefdoms categorized into four major ethnic groups: Tikar, Chamba, Widikum, and Tiv. The chiefdoms have defined boundaries and have throughout their existence expressed ethnic consciousness in ways that amount to violent conflict. 


\section{Context and Operation Mechanism of the JPC}

The creation of the Justice and Peace Commission of the Catholic Archdiocese of Bamenda was underpinned by the inter-ethnic conflicts in the Cameroon's Northwest Region and the importance the Catholic Church attaches to the promotion of justice and peace in the world. The Northwest Region of Cameroon, which corresponds with the area covered by the Archdiocese of Bamenda, has been hit by many inter-ethnic conflicts since colonial times, with some traced back to the pre-colonial period (Nkwi and Warnier 1982). According to Mbah $(2009,11)$, these conflicts occurring between village groups in the region are mostly land/boundary disputes resulting from conflicting ownership claims and boundary disagreements. Though most of these conflicts have their roots in European colonialism, successively under Germany and Britain, the disputes heightened during the post-colonial period due to the administration's inability to tame them. The conflicts have caused economic hardship, population displacement, loss of human life, and destruction of property. Some of the injurious conflicts include Bali Nyonga and Bawock, Balikumbat and Bafanji, Oku and Mbessa, Balikumbat and Bambalang, Esimbi and Musaka, and Baligham and Awing. As these conflicts dragged on in a context of failing government initiatives, authorities of the Archdiocese of Bamenda, who's followers also suffered from the violence, saw the need to promote peace through conflict management and peacebuilding. As such, discussions on the creation of a faith based institution to be given such a task began in the Archdiocese.

Discussions to establish a clerical institution for the promotion of peace equally came at a time when the Vatican had taken steps to enable the Church to act as a global promoter of peace. This was occasioned by the surge in violent conflict and abuse of human rights in the world. The Catholic Church was pushed by this dilemma of conflict to build on its social teachings in view of promoting peace and justice. The teachings of the Church are replete with messages relating to social justice, human development, and peace (Ehusani 1996). Initial teachings issued by popes focused on the plight of workers and general human wellbeing, with no measures taken to ensure their enforcement. In 1961, there was a shift from words to action when Pope John XXIII expanded the Church's social doctrine, with the promotion of peace being emphasized. The Pope released a statement in 1963 titled "Peace on Earth" calling on both Catholics and nonCatholics to enhance world peace. To match this with action, the Pope convened the Second Vatican Council in 1963, with its participants advocating concerted effort in dealing with social problems broadly categorized under injustice, abuse of human rights, and conflict. Since the Second Vatican Council, efforts have been made to enable the Catholic Church to engage practically with society. One of such initiatives was the creation of the Pontifical Commission in 1967 by Pope Paul VI, with the promotion of peace in the world as its blueprint (Odoemene 
2012, 57).

The African continent with its numerous civil wars, inter-ethnic conflicts, and wanton abuse of human rights caught the attention of the Pontifical Council with the holding of a Pan-African Justice and Peace Conference in Lesotho in 1988. Participants who came from across the continent resolved that steps be taken to create permanent justice and peace institutions at national and regional levels by episcopal conferences. Later in 1995, following delays in the establishment of these justice and peace structures, Pope John Paul II reechoed the call in his Ecclesia in Africa: "Aware that in many African countries, gross violation of human dignity and rights is being perpetuated, I ask the Episcopal Conferences to establish where they do not yet exist, Justice and Peace Commissions at various levels. These will awaken Christian communities to their evangelical responsibilities in the defense of human rights" (Pope John Paul II 1995).

This request did not fall on deaf ears as Episcopal Conferences across the continent hastened the creation of justice and peace commissions. In 1995, the National Episcopal Conference of Cameroon responded to the Pope's exhortation by creating a Sub-Commission for Justice and Peace, which today is the Justice and Peace Department of the National Episcopal Conference of Cameroon (JPC 2009). This coincided with the creation of a sub-regional organ-the Association of Episcopal Conferences in Africa and Madagascar (ACERAC) which responded to the Pope's clarion call by putting in place a Justice, Peace and Good Governance Department in 1999. Through this department, ACERAC urged episcopal conferences to heed to the call of creating justice and peace commissions. This was the context in which the Justice and Peace Department of the National Episcopal Conference of Cameroon began working closely with bishops to create Justice and Peace Commissions in the country.

In the Archdiocese of Bamenda, with its numerous conflicts and gross violation of human rights, His Grace, Fr. Paul Verdzekov initiated discussions for the creation of the JPC. This was hastened by the participation of Christians of the Archdiocese in the twin municipal and parliamentary elections of June 30, 2002 as observers (ibid.). After the elections, the Archbishop described the serving of Christians as election observers as evidence of the response of the Church to its social mandate. He further observed: "What you did last June gives me well-founded hopes that, with your involvement and commitment, our Archdiocese should soon be able to boast of vibrant and dynamic justice and peace commissions at all levels as demanded by Pope John Paul II in his PostSynodal Apostolic Exhortation, Ecclesia in Africa" (JPC 2012). To match these words with action, Archbishop Verdzekov established the JPC of the Archdiocese of Bamenda on December 12, 2002 (Shwei 2016, 9). It is a faith based non-profit organization legally recognized by the government of Cameroon.

With a vision hinged on the expectation of a transformed society in 
which there is respect for human dignity, equality, and sustainable peace and development, the JPC is commissioned to work for justice, build peace, and promote socially sustainable development in the light of the Gospel and the social teachings of the Church (JPC 2012). Clearly, therefore, the JPC was established to promote justice and peace across the Archdiocese, build a peaceful society by managing and preventing conflicts, denounce and combat all that degrades and destroys the human person, carry out studies on justice and peace, and heighten awareness on the need to promote and keep peace. These objectives matched the local context of the Northwest Region which was/is known for inter-ethnic conflicts and abuse of human rights. Rolling these social problems away was a responsibility placed on the shoulders of the JPC. Though the institution had many objectives, the interest of this article lies in its intervention in inter-ethnic conflicts.

In order to ensure that the JPC was effective, its members were selected from among priests, nuns, and lay faithful. The JPC at the level of the Archdiocese is made up of twelve elected members, two each from the six deanery commissions together with the staff of the Coordination Office who are appointed by the Archbishop and recruited according to the necessary expertise. The JPC is headed by a Coordinator appointed by the Archbishop. Its pioneer Coordinator was Laura Naddin Ngwa. Under the Coordinator are Program Officers in charge of programs like Human Trafficking headed by Assumta Lum and the Peacebuilding and Conflict Management under the leadership of Elphie Galland. The institution also works with volunteers and has a secretariat at its main office in Bamenda. The members of the commission engaged experts, volunteers, and secretariat staff to keep the JPC running actively throughout the entire Archdiocese. For pastoral reasons, the commission is represented in the Small Christian Communities, Missions, Parishes, and Deaneries and at Diocesan level by elected members. These elections are conducted every three years.

With regards to the sources of income for its work, the JPC obtained some of its funds from allocations made by the Archdiocese of Bamenda. Such funds were not fixed and depended on the projects at hand. Furthermore, funding for its work came from local and foreign partners, especially international non-governmental organizations. From a single funding partner in 2003, the commission has expanded its partnership base to more than ten. Its main funding partners are British High Commission in Yaounde, Catholic Relief Services, the Institute of Peace and Justice San Diego, the United States Department of State, the United States Embassy in Yaounde, Misereor, and MM-Netherlands, among others (Galland 2011). It has been with these funds that this non-profit institution engages in peacebuilding and conflict management in the Northwest Region of Cameroon through a myriad of activities. 


\section{Inter-Ethnic Conflict Management}

The JPC was/is concerned with the arbitration and resolution of inter-ethnic conflicts that were common in the Cameroon's Northwest Region. Though the roots of some of these inter-ethnic conflicts go as far back as the pre-colonial period, most arose from increased identity consciousness among and between village-groups during the colonial period, caused by undue advantages given to particular chiefdoms and the redrawing of ethnic borders by the successive German and British colonial administrations (Mbah 2009). All the inter-ethnic conflicts are anchored on land, with ethnic communities expressing opposing land ownership claims and differences over boundaries. In addition, there is the issue of hierarchical classification of Fondoms; the classification gives room for some of the Fons to lord over those who rank below. This sort of power display makes an already bad situation worse. The conflicts have threatened peace, induced population displacement, caused property destruction, and have stalled local development.

Upon creation in 2002, the JPC investigated these conflicts in the Northwest Region in order to understand how it could intervene in their management. This enabled the Commission to understand why there were ongoing conflicts such as Oku-Mbessa, Bali Nyonga-Bawock, Balikumbat-Bafanji, Balikumbat-Bambalang, Baligham-Awing, Esimbi-Musaka, among many others. The commission found that while land was at the center of these conflicts, the one between Bali Nyonga and Bawock was exacerbated by the hierarchical classification of Fons by the Cameroon government (Galland 2011). Most of these conflicts are sporadic, with each oscillating between moments of calm and violence.

With credible information about the conflicts, the JPC established within its system an Alternative Dispute Resolution (ADR $)^{1}$ unit through which conflicts were managed. The ADR approach permitted the JPC to mediate inter-ethnic conflicts. Quite often a third party engaged by the commission helped disputants through their negotiations in a non-binding fashion. Mediation was intended to stop violence and establish peaceful relations between conflicting parties. Typical cases of its involvement in conflict management could be seen in the JPC's intervention in the violent inter-ethnic conflicts between Bali Nyonga and Bawock.

\section{The Bali Nyonga-Bawock Conflict}

The Bali Nyonga-Bawock conflict is traced to the era of massive population movement and peopling in the Bamenda Grassfields of Cameroon, known today as the Northwest Region. After a tortuous migration from the northern part of Cameroon, the Bali Nyonga acquired their present homeland through military 
conquest and peaceful negotiation in the nineteenth century. Later in 1904, wandering BaTi people from Bansoa were provided settlement in Bali-Nyonga by Fon Fonyonga II. Barely two years after settling in Bali Nyonga, the BaTi chief received a distress call from his brother-in-law, the chief of Bawock and invited him to join him in Bali Nyonga. Bawock, a Bamileke polity, had strained relations with its neighbors, especially Bangante. This caused the Bawock to re-settle as a vassal polity in Bali-Nyonga in 1906 at a place called Kumchu. So, Bali Nyonga consisted of a conglomerate mixture of peoples and groups from different origins and cultures. As Nyamndi $(1984,81)$ notes, the daunting diversity of the Bali Nyonga Empire made governance "a very intricate matter indeed, needing a firm and shrewd hand to bring stability and direction to what looked nearly like a madhouse."

The rise of autochthony in Cameroon instrumentalized sentiments associated with home among the Bali-Nyonga, Bawock, and in other parts of the country. Within the varied Bali-Nyonga Empire, claims about homeland manifested by the Bawock were difficult to reconcile. After years of cohabitation and intermarriage, the Bawock began emphasizing their Bamileke ethnic identity. This was how the seed of a boundary dispute between Bali-Nyonga and Bawock were sown in Mezam, Northwest Cameroon. The misunderstanding degenerated in 2006 when government surveyors began demarcating the boundary of Bali Subdivision and Santa Subdivision in the Mezam Division, Northwest Region. Their work was stopped by Bali-Nyonga youths who destroyed pillar stones as they interpreted the demarcation of the boundary as a veiled attempt by the Bawock to acquire land at the expense of Bali-Nyonga. The Bali-Nyonga also claimed that their Lela Festival shrine is located at the Ntsi-Su'Fu Stream which runs through the disputed site. The Lela Shrine thus became a source of conflict between the two communities given that the Bawock saw Bali-Nyonga ritual activities in the shrine as violation of their territorial sovereignty. Expectedly, the Bali-Nyonga linked Bawock restriction of access to the Lela Shrine to the boundary demarcation they had interrupted. This amounted to the skirmishes of December 2006 (Loh 2007). Although the Fons of Bali-Nyonga and Bawock appealed for calm, more violence followed in March 2007 resulting from the alleged performance of farming rituals in Bawock by Voma, a Bali-Nyonga cult. The members of this cult, going by Bali-Nyonga accounts, were attacked while returning from a ritual site outside of Bawock. A fire in the Bali-Nyonga Palace on March 5, 2007 heightened the tension given that the Bali-Nyonga people saw it as an arson attack by a group from Bawock.

Seeking revenge for the fire at their palace, Bali-Nyonga youths attacked Bawock on March 6. The attack marked the peak of the conflict:

The next day around 300 buildings in Bawock were razed to the ground, livestock was butchered and crops destroyed. Government troops were brought into Bali and 
Bawock to control the situation and prevent further violence... By the end of the day, between 500 and 5,000 people from Bawock had fled the village and large numbers of them stayed away for several weeks. Ultimately around 2,200 people formed a "refugee camp" in the Bamenda Congress Hall... where they received official and charitable aid (Page, Evans, and Mercer 2010, 352).

The events of March 6, 2007 evidenced a long-dragging misunderstanding between Bali-Nyonga and Bawock (Loh 2007; Pokam 2015, 20). The Second Class Fon of Bawock refused to submit to the First Class Fon of Bali Nyonga. The Bawock saw themselves as a sovereign people and considered the Bali-Nyonga to be Nigerians who invaded their land (Pokam 2015). Though the conflict claimed no human life, the material damage inflicted was unprecedented in that locality. The Bawocks were violently chased away from their homes, leaving behind all their belongings. Overall, the conflict between Bali-Nyonga and Bawock hinges on opposing claims over homeland; that is, who has the right to call a particular place their homeland. Hence, the interest difference of this dispute centers on questions about land ownership, home, ethnicity, and exploitation of resources.

Informed of the violent conflict, JPC's Coordinator Laura Anyola Tufon held meetings with her collaborators at the head office in Bamenda in April 2007. The meeting was also held just two weeks after the Senior Divisional Officer (SDO) of Mezam Division at the time, a former member of the Justice and Peace Commission of the Diocese of Nkongsamba, had requested permission from the Catholic Church authority for the JPC of the Archdiocese to collaborate with the administration to resolve the recurring conflict between the two communities. As highlighted in the section on the background of JPC, one of JPC's principal focuses was to be actively involved in conflict resolution and peacebuilding in the Northwest Region. As such, the outbreak of the Bali Nyonga-Bawock conflict in 2006 offered the JPC an opportunity to begin pioneering efforts in conflict resolution. The meeting commissioned JPC's Peace and Development Officer, Galland Elphie, to gather more information on the conflict in view of deploying the ADR to the area for mediation. Members of the commission visited the displaced Bawock people in Bamenda from whom they got more information about the conflict.

In June 2007, the ADR began intervening in the conflict, using dialogue as the primary form of resolution to the dispute. It took active roles in promoting reconciliation and mediation efforts as a means to end the conflict. On separate occasions, the JPC team led by Laura Anyola Tufon held working sessions with the Fons and notables of Bali-Nyonga and Bawock. During these sessions, the JPC official consistently emphasized peace and the avoidance of the use of force. Appeals were made to members of both communities to forgive each other and to follow the example of Christ. Through this, the JPC succeeded in bringing the warring communities to the negotiating table. In October 2007, joint Bali 
Nyonga-Bawock talks were held in Bamenda. It was both a positional dialogue and human-relations dialogue. The parties articulated their diametrically opposed views on the violence that was orchestrated in the two communities (ibid., 21). But the officials of the JPC relegated the underlying issues of the conflict to a secondary place, focusing more on mutual acknowledgement and respect by each party for the other. As both parties were talking, anger and violence vanished. The JPC staff utilized their skills in negotiation and dialogue to enhance communication, direct encounters, and build consensual understanding between Bali Nyonga and Bawock.

With the vicious circle of violence brought to an end by fruitful dialogue, the JPC also ensured that the emergency needs of the displaced people were met. Through the JPC, the Catholic Church successfully brought the two communities together to work on the reconstruction of the houses that were destroyed in Bawock. As a matter of fact, the Bali Nyonga people gave assistance to Bawock as a gesture of reconciliation in December 2007 (Page, Evans, and Mercer 2010, 353). Using its funds, the JPC roofed sixteen houses that were burnt during the violent conflict. The commission equally purchased and installed a corn mill at the boundary between Bali Nyonga and Bawock to serve both communities as a symbol of peace. As calm returned, the JPC organized an ecumenical service in Bawock on March 6, 2008, officiated by Rev. Festus Tam of the Presbyterian Church in Cameroon, Father Henry Wirba of the Catholic Church, and Rev. Samuel Neteder of the Eglise Evangelique du Cameroun (Pokam 2015, 21).

But the underlying causes of the conflict (opposing claims over homeland) remained, requiring long-term negotiations. Since 2012, the JPC staff has been discussing approaches for addressing the substantive issues in the dispute within the framework of a series of workshops. The workshops are yet to result in practical measures for addressing the opposing homeland claims at the heart of the conflict. Thus it is not surprising that the potential for the conflict to recur is high; and thus why the JPC is still pursuing long-term peacebuilding initiatives in the area.

\section{Preventing Inter-Ethnic Conflicts through Peace Education}

Peace education has gained recognition as a pathway to a culture of peace in a human society replete with conflicts. Considering that inter-ethnic conflicts and violence continue to blight the Northwest Region contributing to human suffering and making communities vulnerable to poverty, authorities of the JPC came to the realization that attaining peace should be anchored on the teaching of peace. According to JPC Coordinator Laura Anyola, sustainable peace is predicated on educating future generations on competencies, attitudes, and values that will give the capacity to build and maintain peace (Ngwa and Galland 
2011). In the context of the Northwest Region of Cameroon, peace education was required to offer the population the capacity to understand and transform conflict in their own lives and the community. It was in this context that the JPC designed a peace education curriculum for primary and secondary schools in the Northwest Region in 2011 (JPC 2012). Those who were particularly concerned with the initiative included JPC Peacebuilding Officier Galland Elphie, JPC Coordinator Laura Anyola Tufon, and education authorities. The curriculum provides life skills related to peace education and conflict minimization and prevention to reach youths and the community as a whole (JPC 2011,4). The manual addressed themes like conditions for peace, approaches to resolving conflicts, mediation in schools, human rights and responsibilities, justice, peace, and violence. It came on the heels of the Bali-Nyonga-Bawock, Oku-Mbessa, and Bali-Kumbat-Bafanji violent inter-ethnic conflicts. So targeting young people in primary and secondary schools with a peace education program was aimed at building a culture of peace.

In 2011, the Mbessa Chiefdom, which had experienced conflict for many years with its neighbor Oku, was selected to serve as a pilot village for the peace education program. Implementation started with the training of teachers for primary and secondary schools in Mbessa in April 2011. Spanning three days, the training involved twenty teachers drawn from all the schools in the village (Ngwa and Galland 2011, 49). It acquainted the teachers with the manual, which stressed pedagogical aspects such as techniques of teaching, communication skills, and questioning skills. This led to the effective implementation of the program in primary and secondary schools in Mbessa. From 2012 to 2016, teachers used teaching activities such as role-play, pairs and groups, brainstorming, and whole class discussion to make the program experiential.

Though this resulted in an entrenched culture of peace, recurrence of violence between the two communities persisted, but with little or no destruction (Interview of John Fonkam in Bawock, December 2017). It was initially hoped that the pilot phase of the peace education program was going to be monitored and supervised for possible implementation in the entire region. This agenda was stalled by the outbreak of the Anglophone Crisis in Cameroon in October 2016. The crisis affected the Northwest Region in ways that paralyzed primary and secondary schools. This significantly disrupted the implementation of the peace education program. Its implementation did not cover the entire Northwest Region, with many conflict zones remaining uncovered, especially recent violent conflicts like Balikumbat-Bambalang and Bafut-Bambui. Ethnic tensions are still common across the region and peace education programs cover only two ethnic conflict situations (Oku-Mbessa and Bali Nyonga-Bawock). The program is therefore not sustainable and inclusive, making sustained peace among ethnic communities unattainable for now. Youths in most parts of the region are yet to be empowered with knowledge of the concepts of conflict and peace and 
nonviolent strategies in resolving conflicts. Clearly, the intended transformatory goals of JPC's peace education program are yet to be met.

\section{Limits of the JPC in Conflict Management and Prevention}

There is no doubt that, through the JPC, the Catholic Church has in practical ways expressed religion's potential as a resource for peace by engaging in conflict management and peacebuilding in the Bamenda Grassfields of Cameroon. The JPC has played a pivotal role in the resolution of intractable inter-ethnic conflicts and has toiled to build peace among ethnic communities. This has yielded the public opinion that this faith-based institution does not fail in its conflict management and peacebuilding assignment, causing it to be respected and admired by the local population, civil society organizations, international secular and religious NGOs, and the Cameroon government. In this section, I offer a minority view which presents the JPC as a FBO which has failed in some instances to check conflict. I also argue that the Catholic Church in this part of Cameroon is a double-edged sword as it promotes both peace and conflict.

In the pursuit of the goals of seeking peace, the well-financed JPC has a number of weaknesses which have stalled its work. The most serious weakness of this institution is the lack of professionalism. The organization lacks the capacity to operate professionally when faced with some inter-ethnic conflicts. John Fengo of the Mbessa community observed that peacebuilding actors of the JPC, especially those stationed at the local level, seem to focus more on their faith-based motivation for peacebuilding, forgetting that peacebuilding requires some skills and experiences (Interview of John Fengo John in Mbessa, November 2017). Though these faith-based peace workers have heavy influence in the Northwest Region, checking intractable inter-ethnic conflicts has been a difficult task. Inter-ethnic conflicts are still recurrent in the region despite JPC's extensive grassroots presence. While the JPC has succeeded in cooling down some conflicts such as Bali Nyonga-Bawock and Oku-Mbessa conflicts, it has failed to bring lasting peaceful resolution to these conflicts. The Bamenda Grassfields remains an epicenter of inter-ethnic conflict, with some secular peacebuilding organizations criticizing the JPC for failing to enhance sustainable peace (Fulai 2011). It appears JPC's conflict management activities successfully ended hostilities and failed to turn it into lasting peace. In fact, the deep-rooted causes of these conflicts, including structural, behavioral, and, above all, attitudinal aspects, have not been rolled away. Ethnic groups engaged in intractable conflicts such as Oku-Mbessa, Balikumbat-Bambalang, Esimbi-Musaka, and Balikumbat-Bafanji are yet to be helped by the JPC to explore, analyze, question, and reframe their positions and interests as way of building lasting peace. This failure anchors on the fact that the JPC does not have enough trained personnel and adequate capacity. 
It is even more disturbing that the JPC claims that it is engaged in projects on inter-ethnic conflict management and peacebuilding in the Archdiocese of Bamenda while turning a blind eye to the numerous land conflicts between the Catholic Church and host communities. Across the Archdiocese, there is a mounting wave of land disputes between the Church and local communities such as Weh, Bambui, Wum, Bambili, Nso, Kom and many others (Lang 2017). The conflicts manifest in the form of conflicting borderlines and competing ownership claims. From 2012 to 2014, the Catholic Church, represented by the Archbishop of the Archdiocese of Bamenda Cornelius Fontem Esua, was involved in a serious land conflict with Mbororo pastoralists in Ndzah Village. The Mbororo pastoralist community defended their land rights against attempts by the Catholic Church to dispossess them of land they had occupied since 1904. The Mbororo, with assistance from civil society organizations, initiated strike actions on the disputed land at the entrance to the Cathedral in Bamenda. Under the weight of this public protest and a lawsuit instituted in the Administrative Court of the Northwest Region by civil society organizations, the Archbishop of Bamenda announced that the Church was giving up the land (Nana 2014; Ndaba 2014). Such conflicts are common in the Archdiocese of Bamenda, with the JPC doing nothing to intervene in their resolution. The JPC rather sees the Catholic Church as instrumental in spreading peace and reconciliation throughout the Archdiocese, overlooking how the Church drives land conflicts in the region. But the JPC claims on its website that it is actively engaged in "constructive conflict management and the prevention of violence at all levels in order to build cohesive and stable communities" (JPC 2015). This is an overblown claim given that the faith-based institution has failed in managing some conflicts, does not intervene in every inter-ethnic conflict, and has turned a blind eye to the numerous land conflicts between the Catholic Church and its host communities in the Bamenda Grassfields of Cameroon.

\section{Conclusion}

This article complements the historiography of inter-ethnic conflict and FBOs' intervention in their resolution and prevention in Cameroon's Northwest Region by examining the peace initiatives of the JPC of the Archdiocese of Bamenda. The article has argued that while the JPC has successfully prevented and resolved many conflicts within the Archdioceses, it has also failed in some instances and turned a blind eye to land conflicts generated by the Catholic Church; thus part of the reason why the area is still a theatre of intractable conflict. This complicates the conventional narrative and public perception that the JPC in particular and faith-based institutions in general promote peace as a faith imperative with usual success. The Catholic Church leadership is boastful that the JPC is a results- 
focused faith-based institution that built sustainable peace across the Northwest Region of Cameroon. The commission's strategic framework for 2015-2020 notes how it is "admired for the role it plays in conflict management and peace building within the region" (ibid.). But the truism is that flash points between ethnic communities and even between the Catholic Church and members of host societies are common in the area. Even the Bali Nyonga-Bawock and OkuMbessa conflicts in which the JPC intervened robustly still beg for a permanent settlement. The Northwest Region's consistent status as an inter-ethnic conflictprone zone demonstrates the limits of the JPC in mediating disputes that threaten peaceful co-existence and local development. In fact, sustainable peace remains unattained as the JPC intervenes in inter-ethnic conflicts in a context of limitations anchored on insufficient expertise and lack of a holistic approach.

Concrete measures are therefore required to strengthen the JPC as an institution committed to conflict management and peacebuilding. There is a need to further diversify the conflict resolution programs of the JPC in view of rendering them holistic and inclusive. Its scope in terms of conflict checking needs to be expanded to also cover disputes between the Church and host communities. The expertise of the JPC needs to be beefed up so as to give it the capacity to engage in high-level mediation, training, and peacebuilding at the grassroots in an inclusive manner. Professionalizing the institution and developing its manpower, I believe, will give it the potential to initiate rock solid action which seeks to address root causes of inter-ethnic conflicts in Cameroon's Northwest Region. This can only come through internally-generated critique and assessment which for now are veiled by partial claims that the JPC has accomplished its goal of conflict management and peacebuilding.

\section{Notes}

1. Alternative Dispute Resolution (ADR) is an informal dispute resolution process in which parties meet a professional third party who helps them to resolve their dispute in a less formal and more consensual manner. It is understood as a joint decision-making approach to dealing with social conflict. The third party can be a faith-based actor (the Pope and priests) and religiously inspired leaders.

\section{References}

Appleby, R. Scott. 2006. "Building Sustainable Peace: The Role of Local and Transnational Religious Actors." Paper presented at the Conference on New Religious Pluralism in World Politics, Georgetown University, Washington, DC.

Appleby, Scott, and David Little. 2004. "A Moment of Opportunity? The Promise of Religious Peace Building in an era of Religious and Ethnic Conflict." In Religion and 
Peace Building, eds. Harold Coward, and Gordon S. Smith. New York: State University of New York Press.

Bang, Henry Ngenyam, and Roger Few. 2012. "Social Risks and Challenges in Post-Disaster Resettlement: The Case of Lake Nyos, Cameroon.” Journal of Risk Research 15 (9): 1141-1157.

Bercovitch, Jacob, and S. Ayse Kadayifci-Orellana. 2009. "Religion and Mediation: The Role of Faith-Based Actors in International Conflict Resolution." International Negotiation 14: 175-204.

Ehusani, George Omaku. 1996. A Prophetic Church. Ede: Provincial Pastoral Institute.

Fulai, G. C. 2011. "Bloody Balikumbat/Bambalang Crisis, Women and Children at Risk." https://www.google.com/search?client=firefox-b-d\&q=bloody+balikumbatbambalang+crisis (accessed December 12, 2017).

Galland, Elphie. 2011. "Report on the JPC Peacebuilding and Conflict Management Challenges in the North West Region." The Observer, Bulletin No. 1.

Haynes, Jeffrey. 2009. "Conflict, Conflict Resolution and Peace-Building: The Role of Religion in Mozambique, Nigeria and Cambodia." Commonwealth and Comparative Politics 47 (1): 52-75.

Ilo, Paul. 2015. "Faith-Based Organizations and Conflict Resolution in Nigeria: The Case of the Christian Association of Nigeria (CAN)." Journal of Global Initiatives: Policy, Pedagogy, Perspective 9 (2): 99-108.

Juergensmeyer, Mark. 2003. Terror in the Mind of God: The Global Rise of Religious Violence. Los Angeles: University of California Press.

Justice and Peace Commission. 2009. "Understanding Justice and Peace and the Catholic Social Teaching." Training Manual No. 001A. https://www.justiceandpeacebamenda. org/attachments/article/22/Understanding+Justice+and+Peace+and+the+Catholic+S ocial+Teaching.pdf (accessed March 27, 2019).

Justice and Peace Commission. 2011. "Peace Education Manual for Secondary Schools." https:/www.justiceandpeacebamenda.org/attachments/article/22/Peace+education+s econdary+schools.pdf (accessed on January 18, 2018).

Justice and Peace Commission. 2012. "Milestones of the Justice and Peace Commission, 2002-2012." https://www.justiceandpeacebamenda.org/attachments/article/24/ JPC+MILESTONES.pdf (accessed on April 14, 2019).

Justice and Peace Commission. 2015. “Strategic Framework 2015-2020.” https://www. justiceandpeacebamenda.org/about/strategic-plan-2015-2020 (accessed on April 14, 2019).

Lang, Michael Kpughe. 2017. "Land Disputes Between the Catholic Church and Indigenes of Weh Fondom, 1957-1996." Ghana Social Science Journal 14 (1): 109-138.

Loh, Choves. 2007. "P.M’s Envoy Sizes up Destruction in Bawock/Bali." Cameroon Tribune, March 20.

Mbah, Emmanuel. 2009. "Disruptive Colonial Boundaries and Attempts to Resolve Land/ Boundary Disputes in the Grasslands of Bamenda, Cameroon." African Journal on Conflict Resolution 9 (3): 11-32.

Nana, Sarli Sardou. 2014. "Demolition of Homes and Evictions of Banjah: How the Land Grab Happened." BBC Report, African World Forum.

Ndaba, Usman M. 2014. "Conflicts Between Mbororo and the Catholic Church Ends Positively for Pastoralists.” Making Rangelands Secure, Bulletin No. 5, May. https:// 
www.iucn.org/downloads/bulletinrangelands5.pdf (accessed 28 January 2018).

Ndi, Anthony. 2005. Mill Hill Missionaries in Southern West Cameroon, 1922-1971: Prime Partners in Nation Building. Nairobi: Paulines Publication Africa.

Ndi, Anthony, ed. 2014. A Concise Centenary History of the Catholic Church: Archdiocese of Bamenda, 1913-2013. Bamenda: Archdiocesan Information Service.

Ngwa, Laura Anyola, and Elphie Galland. 2011. "Diocesan Justice and Peace Commission Bamenda: Our Work for Peace and Stability." In Peace Work in Cameroon, eds. Christiane Kayser, and Flaubert Djateng, 48-50. Berlin: Freiburger Graphische Betriebe.

Nichols, Bruce. 1994. "Religious Conciliation between the Sandinistas and the East Coast Indians in Nicaragua." In Religion, the Missing Dimension of Statecraft, eds. Douglas Johnstone, and Cynthia Sampson, 64-87. New York: Oxford University Press.

Nkwi, Paul Nchoji, and Jean-Pierre Warnier. 1982. Elements for a History of the Western Grassfields. Yaounde: SOPECAM.

Nyamndi, Ndifontah. 1984. The Bali Chamba of Cameroon: A Political History. Paris: CAPE.

Odoemene, Akachi. 2012. "Oiling the Frictions in Sociopolitical Conflicts: Faith-based Institutional Leadership of the JDPC in Grassroots Peacemaking in Nigeria." African Conflict and Peace Building Review 2 (2): 51-76.

Page, Ben, Martin Evans, and Claire Mercer. 2010. "Revisiting the Politics of Belonging in Cameroon." Africa: The Journal of International African Institute 80 (10): 345-370.

Pokam, Chanceline. 2015. "The Role of Churches in the Bawock-Bali Nyonga Land Boundary Conflict-2009: A Historical Survey." Long Essay in History, University of Bamenda.

Pope John Paul II. 1995. "Post-Synodal Apostolic Exhortation Ecclesia in Africa of the Holy Father John Paul II to the Bishops Priests and Deacons Men and Women Religious and All the Lay Faithful on the Church in Africa and Its Evangelizing Mission towards the Year 2000." http://w2.vatican.va/content/john-paul-ii/en/apost_ exhortations/documents/hf_jp-ii_exh_14091995_ecclesia-in-africa.html (accessed March 27, 2019).

Reychler, Luc. 1997. "Religion and Conflict." The International Journal of Peace Studies 2 (1): 19-38.

Sampson, Cynthia. 1997. "Religion and Peacebuilding." In Peacebuilding in International Conflict: Methods and Techniques, ed. I. William Zartman, 273-316. Washington, DC: United States Institute of Peace Press.

Shwei, Emmanuel Chunyuy. 2016. "The Church and Inter-Communal Violence: A Study of Land Grabbing and the Role of Catholic Justice and Peace Commission of the Archdiocese of Bamenda, Cameroon." Master Thesis in Diakonia and Christian Social Practice, VID Specialized University.

Wellman, James K., ed. 2007. Belief and Bloodshed: Religion and Violence across Time and Tradition. New York: Rowman \& Littlefield Publishers.

Michael Kpughe Lang is an Associate Professor of Religious History and Chair of the Department of History in the Higher Teacher Training College at the University of Bamenda. He was a Fulbright 


\section{Michael Kpughe Lang}

Scholar at the University of California, Santa Barbara in 2013 and his research interests are in religion and society with focus on ecumenism, missiology, conflict, gender, and medical ministry.

Submitted: February 12, 2018; Revised: September 5, 2018; Accepted: October 22, 2018 